\title{
A paixão da indignação no discurso político de Karl Marx
}

\author{
Elioenai dos Santos Piovezan
}

\section{Considerações iniciais}

"Ein Gestpenst geht um in Europa - das Gestpenst des Kommunismus" (em tradução livre: "Um fantasma paira sobre a Europa, o fantasma do comunismo") Karl Marx, 1848

\begin{abstract}
A célebre frase, em epígrafe, que abre o Manifesto do Partido Comunista A (1848), vale-se da metáfora do fantasmagórico para anunciar que comunistas existem, conhecem seu inimigo - a burguesia - e, a partir do momento de sua revelação, passariam a ter uma atuação explícita na sociedade. A palavra "fantasma" (gestpenst ou geist), além de "espectro" (spektrum), utilizada em algumas traduções, carrega uma acepção relacionada ao sombrio, que remete à paixão do medo, principalmente do que é desconhecido e, no entanto, pode estar próximo. Logo, a admissão de que o comunismo é um fantasma ou espectro cria uma imagem poderosa que apela tanto à superstição medieval quanto à reação do pensamento burguês que desde 1789 enfrenta o crescimento de ideais socialistas e comunistas que questionam o modelo econômico e social vigente. No entanto, o medo é secundário no discurso político de Marx. Subjacente em todo o Manifesto, há na verdade a construção de um sentimento de indignação, dadas as condições de vida e as necessárias transformações da estrutura capitalista de sua época, que busca mover um auditório composto pelo proletariado da cidade e do campo.
\end{abstract}


Dessa forma, mesclando uma linguagem técnica, analítica, histórico-social, com uma linguagem persuasiva carregada de elementos retóricos, Karl Marx (auxiliado por seu amigo Friedrich Engels) produz um discurso que, como tratado político-partidário, conclama a união de todos os trabalhadores do mundo para derrubar a burguesia: classe dominante e proprietária dos meios de produção. Mas, como discurso retórico, permite também uma análise que revela um ethos focado na qualidade do discurso, em que prudência (phrónesis) e logos evidenciam-se em um intricado jogo de raciocínio indutivo e dedutivo; que opera o pathos, notadamente a paixão da indignação, explicitada por um ethos autorizado e chocado diante da burguesia cuja natureza destruidora ele descreve, analisa e faz interagir com um auditório universal (trabalhadores em geral) e também particular (lideranças partidárias, militantes de esquerda), incluindo refutações a um interlocutor que representa a classe patronal.

De certo que Marx não define as paixões em sua obra, mas a utiliza de forma intensa uma vez que dedica toda a sua vida pessoal, profissional e intelectual a uma causa revolucionária. Como filósofo e pesquisador, apresenta um valioso repertório de conceitos que embasam seu discurso, tornando-se, na concepção foucaultiana, um autor singular, um dos "fundadores de discursividade", uma vez que produz a possibilidade e a regra de outros textos, que, por não fazer parte das transformações ulteriores, "permanece necessariamente retirada e em desequilíbrio". 'Basta ver as obras de pensadores e ativistas como Lenin, Trotsky, Gramsci, Lukács, Althusser, Adorno, entre tantos, e ações concretas respaldadas em transdiscursividade e com inspiração marxista, como a Revolução Russa, a Revolução Cubana, a Revolução Nicaraguense, a Revolução Chinesa, entre tantas que buscaram subverter as estruturas do capitalismo.

Nesse sentido, entre os diversos conceitos apresentados por Marx, o materialismo dialético sintetiza bem o raciocínio lógico tanto indutivo quanto dedutivo que considera a experiência de vida e a realidade social como elementos favoráveis, senão indispensáveis, para qualquer análise científica sobre uma determinada sociedade. Rejeita assim o espaço acadêmico como local de atuação, prefere o espaço da mídia cotidiana e do mundo do trabalho em que o embate de ideias é feito em tempo real. Logo, a mobilização do proletariado e suas lideranças partidárias está sempre na ordem do dia.

Fundada no sentimento de indignação, a intensidade de energia dedicada a uma causa (à luta do proletariado) revela Marx como um intelectual apaixonado - logo amado por muitos e odiado por tantos. Um homem das ciências humanas, da economia e da práxis. E esse é o ponto que nos leva a verificar a relação

1 Foucault, 1969, p. 24 
entre objetividade e subjetividade existente na obra marxiana. Obviamente, o objetivo não é abordar um ato retórico à luz de conceitos marxistas, mas antes abordar a escrita de Marx à luz da Retórica com foco nas paixões aristotélicas. Para tanto, consideramos as contribuições de Galinari (2014), quanto às dimensões discursivas das provas retóricas (ethos, pathos e logos), e Figueiredo (2019), quanto à Trajetória das paixões (disponibilidade, identificação, alteração psicofísica, mudança de julgamento e ação).

Tal empreitada nos levou a dividir o presente capítulo em três seções, a saber: Indignação como paixão aristotélica, O subjetivismo e o moderno na obra de Marx e Um olhar retórico sobre o Manifesto do Partido Comunista. As paixões encontram-se no Livro II, de Retórica ${ }^{2}$ e também em A retórica das paixões (2000), obra prefaciada por Meyer, que expõe e analisa os caminhos percorridos pelos filósofos gregos, de Sócrates até Aristóteles, culminando na racionalidade do pathos como "paixão, expressão da natureza humana, da liberdade, comprometido com a ética, portanto com a ação, que transforma a paixão de preferência em virtude". ${ }^{3}$ Em uma tentativa de desmistificar o discurso de Marx como produto do pensamento materialista e, por extensão, extremamente objetivo, buscamos na segunda seção demonstrar, com Chagas (2013) e Berman (1986), o lado subjetivista e modernista do filósofo alemão, elementos que, certamente, colaboram para a constituição de um logos que atua diretamente no pathos de leitores situados em diferentes momentos históricos. Enfim, arriscamos uma análise retórica do discurso político do Manifesto, a fim de concluir que a força discursiva do jovem Marx não está apenas nos conceitos defendidos ao longo do documento, mas no uso de uma linguagem que visa a construir, simultaneamente, um ethos do opressor (o burguês) em que desperta a paixão da indignação no auditório composto essencialmente por oprimidos (o proletariado), o que resulta na construção de um discurso retórico permanente e eficaz.

\section{Indignação como paixão aristotélica}

Se é verdade que somos seres retóricos, ${ }^{4}$ podemos afirmar ser verdade também que todo ser humano é movido por paixões. Há vários campos científicos (Psicologia, Antropologia, Sociologia etc.) que procuram explicar ou, pelo menos, descrever comportamentos individuais ou sociais do ser humano. A área de Linguagens busca esclarecer o fenômeno do funcionamento das intervenções

Aristóteles, 2015

Meyer, 2000, p. XXXV

Ferreira, 2010 
comunicativas (Neurolinguística, Linguística, Teoria da Comunicação, Teoria da Enunciação, Sociointeracionismo, Linguística Textual, Análise do Discurso, Semiótica, Retórica, Pragmática, Sociorretórica etc.). Interessa-nos aqui a Retórica Antiga, apresentada e sistematizada por Aristóteles, notadamente nas obras Retórica e Ética a Nicômaco.

Entretanto, antes de conceituar a paixão, é necessário retomarmos o conceito de Retórica que, para Aristóteles, é "a capacidade de descobrir o que é adequado a cada caso com o fim de persuadir". ${ }^{5}$ Ele refere-se à construção do discurso e elege como uma das funções da Retórica "a faculdade de descobrir os meios de persuasão sobre qualquer questão dada", ${ }^{6}$ portanto uma arte que se vale de provas de persuasão que podem ou não ser produzidas pelo orador. Este não deve abrir mão das provas "inartísticas", ou seja, aquelas que não são produzidas pelo argumentador (testemunhos, documentos escritos), e deve inventar, buscar, as provas artísticas.

Ora, as provas de persuasão inerentes a um discurso são de três espécies: "umas residem no caráter moral do orador; outras, no modo como se dispõe o ouvinte; e outras, no próprio discurso, pelo que este demonstra ou parece

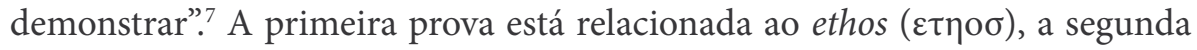

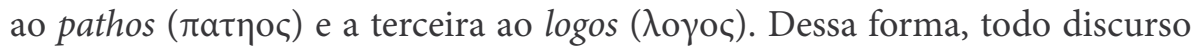
minimamente persuasivo deve mobilizar as três provas retóricas em uma relação simbiótica, colaborativa, que atuam, segundo Galinari (2014), como "três lados' da mesma moeda", uma vez que, superado o dualismo ethos/pathos $\mathrm{x}$ logos, funcionam como "dimensões" de um mesmo discurso.

Ainda com Aristóteles, "três são as causas que tornam persuasivos os oradores, e a sua importância é tal que por elas nos persuadimos, sem necessidade de demonstrações: são elas a prudência, a virtude e a benevolência". Podemos antecipar que Marx, na qualidade de orador do Manifesto, reúne todas elas: é prudente, ao se assentar no logos da materialidade discursiva (é objetivo, racional, cientificista, lógico); é virtuoso, por ser jovem, doutor em Filosofia e respeitado articulista de jornal (utiliza linguagem que expressa conhecimento acadêmico e exerce autoridade em questões políticas); e benevolente, por estar engajado na luta para transformar a sociedade em favor dos trabalhadores (compromisso e militância política com mudanças econômicas e sociais, diferente dos demais filósofos que, segundo o próprio Marx, só se ocupavam de interpretar o mundo, sem desejar transformá-lo).

\footnotetext{
Aristóteles, 2015, p. 62, 1355b

Ibid., p. $62,1355 \mathrm{~b}$

Ibid., p. 63, 1356a

Ibid., p. 116, 1378a
} 
Cabe ressaltar que, na sociedade contemporânea, não é possível enveredar pelo processo da argumentação, "sem que se trate da função que as emoções nele desempenham" e, uma vez superadas as questões que delimitavam o mundo da doxa (opinião, sensibilidade) em relação à demonstração e ao apodítico, a dialética postulada por Aristóteles se apresenta tanto científica quanto subjetiva, expressando as "vivências diárias, portanto, expressão da subjetividade". ${ }^{10}$ Dessa forma, as paixões e os desejos sensíveis também operam no logos, na estrutura do ato retórico, e "recupera[m] o contingente, o hipotético e as modalidades nele compreendidas, do possível, do provável, incluindo o domínio da opinião, relegada por Platão à doxa". ${ }^{11}$

Em A retórica das paixões, Meyer (2000), após elucidar a gênese do pathos, apresenta uma extensa lista de definições indo do pathos às paixões, em uma progressão que revela assunção do pathos à condição de predicado necessário, que é o que nos torna humanos. Elenquemos algumas:

- O pathos como "a voz da contingência, da qualidade que se vai atribuir ao sujeito, mas que ele não possui por natureza, por essência”. ${ }^{12}$

- O pathos como aquilo que "é ambíguo".13

- O pathos como "momento contingente e problemático, que busca reencontrar a natureza das coisas, sua finalidade própria, determinada pela essência". ${ }^{14}$

- O pathos como "lugar impossível da diferença proposicional sem a qual não haveria identidade de substância". ${ }^{15}$

- O pathos como "paixão, expressão da natureza humana, da liberdade, do comprometimento com a ética, portanto com a ação, que transforma a paixão de preferência em virtude" - e esta "exige a reflexão quando, de outro modo, a paixão possa progredir irrefletidamente". ${ }^{16}$

\footnotetext{
9 Mosca, 2017, p. 16

10 Ibid., p. 17

11 Ibid., p. 17

12 Meyer, 2000, p. XXXII

13 Ibid., p. XXXIII

14 Ibid., p. XXXIII

15 Ibid., p. XXXIV

16 Ibid., p. XXXV
} 
- A paixão como "o lugar do Outro, da possibilidade diferente do que somos afinal". ${ }^{17}$

- A paixão como "um estado de alma móvel, reversível, sempre suscetível de ser contrariado, invertido"18

- A paixão como "resposta, julgamento, reflexão sobre o que somos". ${ }^{19}$

Podemos afirmar ainda que o pathos é "o lugar do humano, do contingente, da alternativa, do diferente, a paixão é também expressão da natureza humana, ambígua pelo que é e pelo que não é, remetendo às soluções opostas, aos conflitos, às diferenças entre os seres". ${ }^{20}$ Daí a importância da Retórica em um mundo estruturado na comunicação global, no entroncamento de discursos para as mais diversas finalidades em que o sujeito competente na oralidade e na escrita precisa ter ciência das possibilidades de criação e expressão do livre pensamento.

Em Retórica, Aristóteles afirma que as emoções, compreendidas como paixões, "são as causas que fazem alterar os seres humanos e introduzem mudanças nos seus juízos, na medida em que elas comportam dor e prazer: tais são a ira, a compaixão, o medo e outras semelhantes, assim como as suas contrárias". ${ }^{21}$ Em cada uma das emoções ou paixões listadas por Aristóteles, é importante distinguir três aspectos: [i] o estado de espírito, [ii] contra quem se dirige a emoção e [iii] em que circunstâncias (grifo nosso). Segundo ele, para o orador inspirar qualquer uma das paixões é preciso que haja mais do que um ou dois aspectos presentes em seu discurso. ${ }^{22}$ Ora, o discurso político geralmente inflama o auditório e espera levá-lo a deliberar a favor de sua causa em momentos específicos. Por isso, sua força e penetração são efêmeras em seu valor informativo e propositivo. Por outro lado, poucos discursos como o Manifesto possuem uma vivacidade dada a construção calcada em um pensamento sólido, fruto de reflexões que buscam afetar um auditório amplo em contexto concomitantemente mediato e imediato, próximo e distante no tempo e no espaço.

Dessa forma, em [i], o termo utilizado por Aristóteles para "estado de

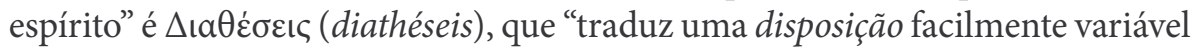
ou um estado de espírito físico, psíquico ou moral que se altera e que depende

\footnotetext{
17 Ibid., p. XXXV

18 Ibid., p. XXXIX

19 Ibid., p. XL

20 Mosca, 2017, p. 17

21 Aristóteles, 2015, p. 116, 1378a

22 Aristóteles, 2015
} 
do hábito (ethos) e da maneira de ser de cada um". ${ }^{23}$ Para o estagirita, está claro que o orador deve dispor, por meio do ato retórico, os seus ouvintes de modo que se sintam em condições de se converterem em determinada paixão, o que torna os oponentes culpados daquilo que a provoca e como indivíduos dotados de um caráter com condições de a excitar. ${ }^{24}$ Em outras palavras, em uma situação retórica, o orador precisa conhecer seu auditório para movê-lo de acordo com as paixões suscetíveis e implicadas no conteúdo temático, para que haja adesão. O estado de espírito envolveria, nesse sentido, ânimos, necessidades, desejos, ou seja, predisposições humanas passíveis de conduzir a uma ação.

Aristóteles destaca a maneira de ser de cada um, a idiossincrasia, que em determinadas situações pode ser amplificada e incorporada a uma coletividade. Obviamente que os ouvintes ou leitores (hoje telespectadores ou internautas) podem compreender uma mensagem de diferentes formas, a partir de seus conhecimentos prévios e ideologias cristalizados. No entanto, o que explicaria o "estado de espírito" de uma multidão que marcha obstinada, como uma corrente humana, contra uma tropa de choque fortemente armada e alinhada com ordem para atirar? Que discurso alimenta e move manifestantes a ocuparem um prédio do governo para exigir algum direito ou a revogação de uma lei injusta? Que paixão inspiraria ações humanas contundentes, que levaram à derrubada de governos, como a Revolução de Outubro, na Rússia de 1917, ou a Primavera Árabe, no Egito, Tunísia, Líbia e Síria, entre outros, desde 2010? Por mais diferenças culturais que haja entre as pessoas dos diferentes países e por mais diferenças pessoais, políticas e ideológicas que haja entre os membros de uma mesma sociedade, parece haver uma paixão em comum que move a todos igualmente: a indignação.

Em [ii], é preciso determinar contra quem se dirige a emoção que se quer suscitar no auditório e, por conseguinte, conhecer bem o leitor/ouvinte/ telespectador para que o discurso produza os efeitos de sentido esperados, a adesão dos espíritos - às vezes negociada, às vezes não, que pode operar no consenso ou no dissenso. Para Aristóteles (2015), a questão parece bem resolvida, pois "a retórica tem por objetivo formar um juízo (porque também se julgam as deliberações e a ação judicial é um juízo)", logo "é necessário procurar não só que o discurso seja demonstrativo e digno de crédito, mas também que o orador mostre possuir certas disposições e prepare favoravelmente o juiz". ${ }^{25}$ Se atribuirmos ao auditório os papéis de juiz e assembleia, apostamos no seu julgamento acerca de deliberações a partir de argumentos fundados na sua 
percepção de mundo, nos valores construídos e aceitos socialmente. Teríamos assim que o pathos, para além de ser "tentativa", "expectativa" ou "possibilidade" de despertar emoções no auditório, ser sim suas "garantias simbólicas" ou ainda "seus elementos linguageiros deflagradores".

É nesse ponto que a parte lógica do discurso, que atua no plano formal, macro e microestrutural, valora a presença do pathos como desencadeador de emoções que buscam uma ação-responsiva do auditório a depender do contexto retórico (contido no "perfil dóxico") e de seus "valores, engajamentos e imaginários", que, como linguagem e seus atributos - "uma analogia, uma disposição sintática, um item lexical, um estilo, um tema, um conteúdo implícito etc." - podem atingir um "estatuto patêmico". ${ }^{27}$ Por isso, para além do logos e de todo o aparato formal exigidos em um discurso, preparar o auditório é alimentá-lo com elementos que movam suas paixões em um exercício de empatia, como uma transposição da paixão que salta do orador para encontrar acolhida no auditório. O orador compartilha sua indignação convicto de que o auditório sinta o que ele sente para que todos sintam juntos a mesma indignação.

Nesse sentido, de acordo com Aristóteles (2015), os pares compaixão e indignação "são próprios de um caráter nobre, porque devemos não só sentir tristeza e compaixão com os que sofrem um mal imerecido, como sentir indignação contra os que imerecidamente gozam de felicidade". ${ }^{28}$ Logo, podemos intuir, no limite, que "a indignação é uma pena sentida relativamente a quem parece gozar de uma felicidade imerecida", e os sujeitos causadores de indignação são os maus que se aproveitam "da riqueza, do poder e de coisas semelhantes". ${ }^{29}$ Para quem é mais antigo, a sua riqueza e seus bens podem parecer mais "naturais", mas se quem possui um bem ou o adquiriu recentemente e a ele deve a sua prosperidade, isso provoca, segundo Aristóteles (2015), "mais indignação". Isso explicaria por que

os novos-ricos causam mais pena do que aqueles que o são há muito tempo, e de nascença; o mesmo acontece com os governantes, os poderosos, os que têm muitos amigos, os bons filhos e coisas do mesmo gênero. E, se tais bens lhe servem para adquirir outros, a nossa indignação mantém-se mais acesa. Daí que nos causem mais aflição os novos-ricos que assumem o poder porque são ricos, do que os mais antigos. ${ }^{30}$

26 Galinari, 2014, p. 279

27 Ibid., p. 279

28 Aristóteles, 2015, p. 138, 1386b

29 Ibid., p. 138, 1387a

30 Ibid., p. 139, 1387a 
A indignação, em toda sua extensão, parece ter como causa alguém que injustamente ocupa um posto ou papel social. Obviamente, na Grécia dos séculos IV e III a.C., valores éticos e morais expressavam-se no exercício da cidadania como desdobramento da democracia. Mesmo não havendo o conceito de luta de classes, resta claro que os ricos eram vistos com desconfiança e suscetíveis de despertar indignação por certas posturas. Ser rico e acumular mais riqueza ou ocupar um mandato para dirigir a pólis parecem atitudes incompatíveis com o sentimento de igualdade e indesejadas pela sociedade (ou parte dela), uma vez que representa algo que não é merecido.

Por fim, a pensar em [iii], as circunstâncias, entendemos que se trata da situação retórica que, no mundo da doxa, equivaleria a uma combinação de fatores que interferem na vida cotidiana a ponto de exigir uma mudança, uma ação. Em um plano de contingências, das verdades possíveis e da plausibilidade dos argumentos, a resolução se daria pelo embate entre discursos antagônicos na busca de acordos ou não. Consideramos ainda que, se na doxa é recorrente que os indivíduos apresentem diferentes pontos de vista acerca de uma mesma questão, existem as circunstâncias que revelam ideologias arraigadas em percepções conformistas e que não aceitam mudança alguma da "paisagem.".

De um lado, o pêndulo das circunstâncias tenderia para a manutenção do status quo, consciente ou inconscientemente; de outro lado, o pêndulo apontaria para a necessidade de superar as aparências de um mundo supostamente ordenado para efetivamente transformá-lo. Assim, a paixão da indignação pode mobilizar desde uma faxineira inconformada com o aumento do preço de produtos básicos e essenciais à sua sobrevivência até um país inteiro que só entende como solução a troca de um governo ou mesmo da estrutura econômica que o mantém no poder.

Cremos ainda que as circunstâncias que despertariam o sentimento de indignação podem estar escamoteadas pela falsa percepção de normalidade e da ideia dominante de que "sempre foi assim". Aristóteles (2015), atento ao cotidiano e às questões práticas da vida social de seus contemporâneos, teria constatado certo conformismo a respeito da natureza das coisas. A realidade deveria, pois, ser sempre questionada e, por que não, problematizada a fim de que cada ser humano tivesse o que lhe caberia por merecimento. Afirma o filósofo:

uns parecem ter o que lhes pertence, outros não; com efeito, o que sempre se manifestou a nós num certo estado parece ser assim na realidade, de tal modo que os outros dão a sensação de possuírem o que não lhes

31 Bazerman, 2015 
pertence. Ora, nem todos os bens são dignos do primeiro que aparece (...). Portanto, se um homem de bem não obtém o que é proporcional à sua virtude, isso é motivo de indignação. ${ }^{32}$

Mais uma vez as relações humanas aparecem pautadas pelas condições não só de igualdade, mas também de inferioridade e superioridade. Nesse ponto, Aristóteles acreditava que "não é justo que aqueles que não são nossos iguais sejam julgados dignos de bem iguais aos nossos" e "se uma pessoa é boa e virtuosa" é porque neste caso "julga retamente e odeia a injustiça”. ${ }^{33}$ Logo, uma circunstância de injustiça é sempre um disparador de indignação.

Aristóteles conclui sua exposição sobre a indignação, afirmando que "se o nosso discurso predispõe devidamente os espíritos dos juízes e lhes mostra que os que invocam a sua compaixão não a merecem, pelas razões que apresentam, antes merecem que ela lhes seja recusada, então será impossível suscitar em compaixão". ${ }^{34}$ Assim, o auditório, uma vez revestido do papel de juiz que delibera sobre uma causa, tende a eliminar contradições inclinando o pêndulo para garantir a dignidade pelo merecimento.

Se, em última análise, em uma relação dialógica - portanto não de sobreposição - "as paixões refletem, no fundo, as representações que fazemos dos outros, considerando-se o que eles são para nós, realmente ou no domínio de nossa imaginação", então, a indignação, assim como todas as demais paixões elencadas por Aristóteles, trata-se, como vimos anteriormente, de uma “paixão-resposta à imagem que formamos do outro, sobretudo do que o outro experimenta a nosso respeito". ${ }^{35}$ Cabe ao orador equacionar a paixão que o afeta e ter a capacidade de transformar a sua convicção na convicção do auditório.

Por fim, uma vez demonstrados o estado de espírito, contra quem dirigir o discurso e as circunstâncias para que isso ocorra, bem como a paixão da indignação como contraponto da compaixão, concluímos por ora, que um orador competente deve conhecer muito bem a natureza do seu auditório e qual injustiça lhe despertaria a indignação. Em sentido amplo, conforme Meyer (2000), "as paixões constituem um teclado no qual o bom orador toca para convencer". ${ }^{36}$ Vimos que o objeto-causa da indignação está sempre relacionado à falta de merecimento de um determinado bem. E as circunstâncias em que uma paixão pode ser despertada dependem da capacidade do auditório em perceber os fatos

Aristóteles, 2015, p. 139, 1387a

Ibid., p. 140, 1387b

Aristóteles, 2015, p. 140, 1387b

Meyer, 2000, XLI

Ibid., p. XLI 
A paixão da indignação no discurso

político de Karl Marx

e relacioná-los com as imagens criadas pelo ato retórico. Assim, o objeto-causa pode existir em circunstâncias explícitas ou implícitas, cabendo ao auditório o trabalho de desvendar as falsas aparências pela força discursiva exposta pelo orador atento e competente.

\section{O subjetivismo e o moderno na obra de Marx}

A produção intelectual de Marx começa em um contexto conturbado na Europa: a derrota dos ideais revolucionários na França, a ascensão de governos despóticos alinhados à nobreza resistente na Alemanha, a formação de um exército de crianças, mulheres e homens explorados pelo capital industrial na Inglaterra, a falta de liberdade que forçava os ativistas socialistas e comunistas a trabalharem na clandestinidade, a existência de células comunistas em vários países da Europa com seus membros convictos da necessidade irrefutável de dirigir a revolução comunista para derrotar a burguesia. Nesse cenário, a transformação radical da sociedade seria realizada pelas forças revolucionárias que, na concepção de Marx, foram criadas inevitavelmente pela própria existência do capitalismo. Era o proletariado, também considerado como "forças produtivas", que possuía a tarefa de tomar o estado, extinguir a propriedade privada dos meios de produção e, consequentemente, decretar o fim da luta de classes.

Desse modo, o discurso político de Karl Marx reflete o contexto retórico de seu tempo, com os desafios impostos aos democratas, socialistas e comunistas, que exigiam a formação de uma liderança política que conduzisse as camadas exploradas da sociedade para enfrentar os governos representantes do Capital. Na década de 1840, Marx já era doutor, defendera a tese A diferença das filosofias da natureza em Demócrito e Epicuro ${ }^{37}$ e vivia financeiramente da publicação de artigos para jornais de esquerda. As bases de seu pensamento passavam pelas teorias de Hegel, mas esbarravam na contradição de classes como elemento concreto, o que o levaria a rever o conceito de imanência do homem natural, substituindo-o pela prevalência do homem social.

Logo, o discurso do jovem Karl Marx é marcado por ironia e refutações, num jogo de palavras que ao mesmo tempo nocauteia seus adversários e conclama o auditório a se organizar e a agir. Em O 18 Brumário de Luís Bonaparte (1852), por exemplo, descreve e analisa detalhadamente os principais acontecimentos dos anos que antecederam o golpe de estado do sobrinho de Napoleão

37 Disponível em: <http://www.gepec.ufscar.br/publicacoes/livros-e-colecoes/marx-e-engels/filosofia-danatureza-em-democrito-e-epicuro.pdf/view>. Acessado em: 19 mar. 2020 
Bonaparte. ${ }^{38} \mathrm{O}$ título da obra já carrega uma forte ironia ao comparar o autoproclamado imperador ao golpe dado por seu tio em novembro do oitavo ano da Revolução Francesa.

Já o Manifesto do Partido Comunista (1848), escrito como tarefa solicitada pela Liga dos Comunistas (fundada por Marx e Engels após derrotarem a ala do líder anarquista Proudhon, fundador da até então Liga dos Justos), é ao mesmo tempo um estudo das relações sociais do Capital e do Trabalho e um documento programático para a atuação dos comunistas de toda a Europa e do mundo. Após a publicação do Manifesto, Marx passa a viver exilado na Inglaterra, onde escreve sua obra-prima, O Capital (1867), e passa seus dias até sua morte em 13 de março de 1883. Embora represente sua fase madura, O Capital traz os conceitos elaborados e discutidos desde sua juventude.

Embora exista farta literatura acerca da vida e do pensamento de Marx, poucos pesquisadores abordaram dois aspectos que consideramos importantes - senão determinantes - para a nossa análise: o subjetivismo e o modernismo em Marx. Em relação ao primeiro, é recorrente a ideia de que o pensamento de Marx sobre a subjetividade é comprometido por seu forte traço materialista e determinista, visto como fenômeno secundário diante da objetividade da vida como as relações de produção entre capital e trabalho que tornam viáveis a vida humana. Esse pensamento inviabilizaria, em princípio, uma abordagem acerca do subjetivismo em sua obra que poderia ser, segundo Chagas, "uma reflexão rica e complexa". ${ }^{39}$

Em duas de suas obras, por exemplo, Marx afirma que a vida determina a consciência e não o oposto (A ideologia alemã, 1845-1846) e que "não é a consciência dos homens que determina o seu ser, mas, ao contrário, é o seu ser que determina a sua consciência". ${ }^{40}$ No entanto, para Chagas (2013), Marx refere-se a uma vida social humana e não mais vida em geral, abstrata. Dessa forma,

o ser social, que determina a consciência, está, por sua vez, condicionado historicamente pela produção material da vida, produção essa que significa não só produção econômica (economicismo), mas produção dos meios necessários à vida, à sobrevivência huma-

38 O golpe de Estado de 18 de brumário do ano VIII (brumário, palavra derivada de "bruma" ou "névoa", em francês - pelo calendário da Revolução Francesa, correspondente a 9 de novembro de 1799 pelo calendário gregoriano) iniciou a era do governo napoleônico na França (WIKIPEDIA, 2020). Disponível em https:// pt.wikipedia.org/wiki/18_de_brum\%C3\%A1rio\#: :text=O\%20golpe\%20de\%20Estado\%20de,do\%20 governo\%20napole\%C3\%B4nico\%20na\%20Fran\%C3\%A7a. Acessado em 15jul2020

39 Chagas, 2013, p. 63

40 Prefácio de "Para a crítica da Economia Política”, 1859 
na, que envolve tanto produção de bens materiais quanto de bens imateriais, produção de objetividade e subjetividade, de elementos objetivos e subjetivos. ${ }^{41}$

Ora, a interpretação dominante sobre a obra de Marx não considera esse viés que aponta para "uma unidade ou práxis como mediação entre a objetividade e subjetividade, entre o material (econômico) e o espiritual, entre a base e a superestrutura" ${ }^{42}$ Após refutar a ideia de uma prevalência do sujeito econômico em detrimento do indivíduo como sujeito histórico, Chagas (2013) explica que, nas Teorias da Mais-Valia, Marx apresenta uma conexão entre a produção intelectual e a material e que esta última não deve ser considerada como "categoria geral, mas em "forma histórica determinada". E conclui que "não há em Marx uma supervalorização do aspecto socioeconômico em relação à dimensão da 'superestrutura", 43 ou seja, para o filósofo alemão, não se trata de uma valorização, em que uma é mais importante do que a outra, ou em que uma é determinante e ativa e a outra determinada e passiva, mas de "uma recíproca de uma sobre a outra". ${ }^{4}$

Para Marx, a subjetividade, como consciência, não é uma atividade em segundo plano, pois "é, precisamente, com base na consciência das circunstâncias em que a vida é produzida que o sujeito reconstrói, transforma e apreende o mundo, e adquire para si a sua liberdade" ${ }^{45}$ Nesse aspecto, o filósofo alemão reconhece como superestrutura "os preconceitos, as ilusões, as convicções, os princípios, ou seja, a visão de mundo de uma classe social, o seu modo de pensar, criado por suas condições materiais de vida" ${ }^{46} \mathrm{E}$ é por meio dessas representações, no âmbito "superestrutural", que os sujeitos "assumem seus interesses, expressam a maneira de enxergar a sua existência na sociedade, a consciência que eles têm das condições reais da sua existência, não ocultando, pois, os seus interesses, as suas reais motivações". ${ }^{7}$ Nesse ponto, podemos inferir que o homem, por mais que seus discursos pareçam objetivos, é um ser que carrega emoções e as direciona ao outro em contendas de convencimento e persuasão.

Na obra Tudo que é sólido desmancha no ar (1986), Berman lança um interessante olhar sobre o aspecto modernista e linguagem literária

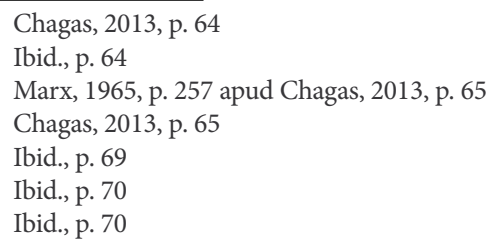


na obra de Marx. Para o autor, o dualismo que considera o "modernizar" relacionado a economia e política, e o "modernismo" relacionado a arte, cultura e sensibilidade, e situa equivocadamente Marx na literatura sobre modernização, não faz sentido. ${ }^{48} \mathrm{Como}$ argumento inicial, Berman garimpa do Manifesto do Partido Comunista, o trecho: "Tudo que é sólido desmancha no ar", ${ }^{49}$ e encontra nele "ambição cósmica, grandeza visionária da imagem, força altamente concentrada, subtons vagamente apocalípticos, ambiguidade de seu ponto de vista" que afirma se tratar de "traços característicos da imaginação modernista" com qualidades encontráveis em "Rimbaud ou Nietzsche, Rike o Yeats". ${ }^{50}$ A intenção não é fazer uma crítica literária, mas situar Marx como um autor modernista que problematiza os valores e percepções de seu tempo e busca compreender as causas das diferenças sociais que abatem as sociedades modernas.

O autor identifica no Manifesto a admiração que Marx revela acerca da força diluidora - e dialeticamente demonstrada - que subjaz ao processo de modernização burguês em seu clímax revolucionário e à "grande realização burguesa" de "liberar a capacidade e os esforços humanos para o desenvolvimento: para a mudança permanente, para a perpétua sublevação e renovação de todos os modos de vida pessoal e social". ${ }^{51}$ Ao mesmo tempo que reconhece tais realizações, o pensamento marxista considera, paradoxalmente, que "o problema do capitalismo é que, aqui como em qualquer parte, ele destrói as possibilidades humanas por ele criadas", ${ }^{52}$ o que aponta para a necessidade de sua superação que seria uma sociedade comunista. Essa visão é expressada nas linhas: "Em lugar da velha sociedade burguesa, com suas classes e seu antagonismo de classes, teremos uma associação em que o livre desenvolvimento de cada um será a condição para o livre desenvolvimento de todos". ${ }^{53}$

Contraditoriamente, no capitalismo, ao mesmo tempo em que constrói, o homem destrói. O pensamento marxista denuncia a criação em que a criatura se revolta contra o seu criador. No Manifesto, traz a imagem do feiticeiro burguês que, na descrição de Berman (1986), descende do Fausto de Goethe e também de Franskenstein de Mary Shelley, ambas figuras literárias e míticas, que insistem na ampliação dos poderes humanos por

48 Berman, 1986, p. 101

49 Marx; Engels, 2015, p. 66

50 Berman, 1986, p. 102

51 Ibid., p. 108

52 Ibid., p. 110

53 Marx; Engels, 2015, p. 89 
A paixão da indignação no discurso

político de Karl Marx

meio da ciência e da racionalidade, desencadeando "poderes demoníacos que irrompem de maneira irracional, para além do controle humano, com resultado horripilante" ${ }^{54}$ Por sua vez, a burguesia se moveria dentro dessa "trágica órbita". Assim, Marx

situa o oculto em um amplo contexto mundial e mostra como, através de um milhão de fábricas e usinas, bancos e escritórios, os poderes sombrios operam em plena luz do dia e as forças sociais são impelidas em direções ameaçadoras pelos insaciáveis imperativos de mercado, que nem o mais poderoso burguês seria capaz de controlar..$^{55}$

Trata-se de uma "antítese radical" em que, na visão de Marx, "os aprendizes de feiticeiro, membros do proletariado revolucionário, estão dispostos a arrebatar o controle das modernas forças de produção das mãos da burguesia fáustico-franksteiniana", transformando tais "forças voláteis, explosivas, em fontes de beleza e alegria para todos" e conduzindo "a história trágica da modernidade a um final feliz" ${ }^{56}$ Por tal conteúdo, expressividade e construção de linguagem, o autor considera o Manifesto como a "primeira grande obra da arte modernista". ${ }^{57}$

O autor ainda abordará outros aspectos do Manifesto, como a imagem da nudez do "homem desacomodado", em que a burguesia contribuiria com o rompimento dos laços feudais que submetiam os homens aos seus "superiores naturais", deixando entre os homens somente o laço de seus "interesses nus". Assim, as revoluções burguesas retiraram os véus "da ilusão religiosa e política", revelando a exploração e o poder como são; expondo a crueldade e a miséria como "feridas abertas" e, ao mesmo tempo, criando as condições para o proletariado resistir e se rebelar sempre que "não estiverem recebendo nada valioso em troca". ${ }^{58}$

Cabe ressaltar que na época de Marx, a Inglaterra e a França eram terrenos férteis aos ideais revolucionários, pois a indignação com o capitalismo era geral e intensa. Nas décadas seguintes, a burguesia teria criado um mercado para ideias radicais que necessitariam de "perturbações", "distúrbios" e "agitação", pois ela "se nutre e se revigora daquilo que se lhe opõe, 
torna-se mais forte em meio a pressões e crises do que em tempos de paz, transforma inimizade em intimidade e detratores em aliados involuntários" ${ }^{59}$

Enfim, estamos diante de um poderoso discurso político que combina as disposições de um auditório suscetível a se indignar (estado de espírito), dada a desigualdade social e injustiça na vida prática (circunstâncias), com uma linguagem que apresenta figuras, narrativas e demais recursos retóricos e cria no imaginário do auditório um efeito patêmico que conduz à mudança de julgamento e à ação (contra quem se indignar).

\section{Um olhar retórico sobre o Manifesto do Partido Comunista}

Como ponto de partida para nossa análise, concordamos com Galinari (2014) ao afirmar que "argumentação e retórica não possuem nenhuma diferenciação, e referem-se indistintamente a todos e quaisquer procedimentos discursivos aptos a produzir intensidades de adesão variadas numa situação específica" ${ }^{60}$ Com isso, entendemos que um discurso, qualquer que seja o gênero textual ou discursivo, possui graus mínimo ou máximo (e nunca grau zero) de retoricidade, uma vez que se realiza sempre numa relação de interação com o outro.

Desse modo, todo ato retórico (como produção de discurso) pressupõe um ato responsivo, e o modo como o orador concebe seu auditório influenciará na busca por argumentos, suas estratégias argumentativas, sua busca por um caminho em como entrar no debate (inventio); na correlação das dimensões micro e macro-estruturais como as progressões temática e semântica e a forma composicional (dispositio); na modalização da linguagem, escolhas lexicais e construção de efeitos de sentido (elocutio); até a circulação e efetiva recepção calculada do discurso (actio).

O Manifesto do Partido Comunista possui uma breve introdução seguida de quatro partes: I - Burgueses e proletários; II - Proletários e comunistas; III - Literatura socialista e comunista (subdividida em 1 . O socialismo reacionário; 2 . $O$ socialismo conservador ou burguês; 3 . O socialismo e o comunismo crítico-utópico); e IV - Posição dos comunistas em relação aos diferentes partidos de oposição.

Como documento político-partidário, o Manifesto funciona como uma carta de intenções que situa os setores sociais, explica as contradições existentes

59 Ibid., p. 135

60 Galinari, 2014, p. 261, grifos do autor 
na sociedade, descreve e analisa os agentes políticos e conclui que a "transformação violenta de toda ordem social" é a única forma de alcançar os objetivos dos comunistas. Para o presente estudo, abordaremos apenas as duas primeiras partes que contêm elementos suficientes para a finalidade de nossa exposição: verificar o poder retórico com foco nas paixões aristotélicas.

No exórdio, a parte introdutória do discurso, Marx afirma que o comunismo já é reconhecido como "força poderosa por todos os poderes europeus". O que faltava, no entanto, era os comunistas exporem o seu "modo de ver, os seus objetivos, as suas tendências, e de contraporem à lenda do fantasma do comunismo um Manifesto do próprio partido". ${ }^{61} \mathrm{O}$ discurso mantém-se na terceira pessoa, mas traz o sentido de coletividade de uma organização que está ciente de iniciar um embate sem volta contra uma classe poderosa: a classe dominante.

Na parte I- Burgueses e proletários, a mais extensa do Manifesto, Marx inicia com a clássica tese que sintetiza boa parte do seu pensamento: "A história de toda a sociedade até hoje tem sido a história das lutas de classes". ${ }^{62}$ Nas linhas que seguem, o filósofo alemão passa a analisar a origem das lutas de classes e, para tanto, modula o discurso para a primeira pessoa do plural, encurtando assim a distância para com seu auditório. Vai desvendando, perscrutando, delineando as etapas da história das sociedades que culminou na transformação de servos medievais em cidadãos livres dos burgos e, posteriormente, em ricos comerciantes, até assumirem as rédeas política e econômica dos seus países.

Um feito peculiar é que a burguesia teria, na época de Marx, "simplificado os antagonismos de classe", dividindo a sociedade em duas grandes classes em confronto direto: "a burguesia e o proletariado". ${ }^{63}$ Aqui tem início um movimento interno na estrutura do discurso do Manifesto que busca despertar no auditório uma consciência de classe ao mesmo tempo em que inicia a construção da indignação necessária para mover o proletariado e suas lideranças, que reconhecem um inimigo em comum que precisa ser derrotado. $\mathrm{O}$ orador busca atingir o "terreno emocional" do leitor, uma vez que "é necessária uma disponibilidade afetiva por parte do auditório, que permita criar espaço para a paixão preconizada por quem profere $\mathrm{o}$ ato argumentativo". ${ }^{64}$

Tal disponibilidade atua, como vimos, no estado de espírito do sujeito em que as emoções podem ser "disparadas" de acordo com a recepção e identificação que o auditório faz do orador. É a empatia necessária criada numa espécie de combinação entre o ethos e logos para operar a dimensão lógica na dimensão

\footnotetext{
61 Marx; Engels, 2015, p. 61

62 Ibid., p. 62

63 Ibid., p. 63

64 Figueiredo, 2019, p. 14
} 
emotiva do discurso. Ora, o discurso, principalmente o escrito, é proferido pelas palavras do orador. Logo, a escolha léxica será determinante para criar no auditório "estados ou processos cognitivos", que Figueiredo (2019) afirma serem: "sensações ou percepções", "impressões sensíveis" e "impressões racionais". ${ }^{65}$

Nesse sentido, a primeira parte do Manifesto funciona como catalizador de sensações e impressões do leitor para que se identifique com o orador e as circunstâncias que ele apresenta. Assim, o objeto-causa da indignação, a burguesia, é em um primeiro momento alvo de elogios e reconhecimento de seus feitos, como vemos em: "A burguesia desempenhou na história um papel altamente revolucionário", ${ }^{66}$ para em seguida ser alvo de uma crítica que busca inverter as sensações ou impressões do auditório, como na afirmação: "A burguesia rasgou o véu sentimental da família, reduzindo as relações familiares a meras relações monetárias". ${ }^{67}$

As "imagens mentais" criadas pelo orador apresentam a burguesia como uma classe social que cumpriu um papel necessário e até inevitável para superar as relações feudais. No Manifesto, isso é recorrente, como podemos observar em:

A burguesia expôs que a exibição brutal de força na Idade Média, que os reacionários tanto admiram, encontrou o seu encaixe aperfeiçoado na mais indolente preguiça. Foi ela quem primeiro demonstrou o que a atividade dos homens pode conseguir. Realizou maravilhas maiores que as pirâmides egípcias, os aquedutos romanos e as catedrais góticas, conduziu expedições mais audazes que as antigas migrações de povos e das Cruzadas. ${ }^{68}$

Entretanto, as transformações vêm acompanhadas de contradições que, segundo o documento, vão pavimentando o caminho de outra revolução. Nessa fase, a construção do discurso busca alterações psicofísicas no auditório. A desconcertante trajetória da economia controlada pela burguesia, leva o auditório a experimentar uma sensação de desprazer, dor ou angústia, quando não medo ou ódio, uma vez que vive, segundo o Manifesto, sob constante ameaça de desemprego, exploração, violência. É o que verificamos na passagem a seguir em que o orador utiliza argumentos de causa e consequência para formar novas imagens mentais que, ao afetarem a alma, afetam o corpo do auditório, como a privação de alimento em consequência do desemprego: 
Nas crises comerciais é regularmente destruída grande parte, não só dos produtos existentes, como das forças produtivas já criadas. Nas crises emerge uma epidemia social que teria parecido um contrassenso em épocas anteriores - a epidemia da superprodução. A sociedade vê-se de repente retransportada a um estado de momentânea barbárie; parecelhe que a fome, ou uma guerra universal de devastação, lhe cortaram todos os meios de subsistência; a indústria e o comércio parecem-lhe aniquilados. E por quê? Porque a sociedade possui civilização em excesso, meios de subsistência em excesso e comércio em excesso. As forças produtivas de que dispõem deixam de servir para a promoção das relações de propriedade burguesas. Pelo contrário, tornaram-se demasiado poderosas para essas relações, e são por elas tolhidas; e assim que superam esse obstáculo inserem a desordem em toda a sociedade burguesa. (...) E como a burguesia supera essas crises? Por um lado, pela destruição forçada de uma massa de forças produtivas; por outro, pela conquista de novos mercados e pela exploração mais profunda de mercados velhos. A que leva isso, então? À preparação de crises mais generalizadas e mais graves, à redução dos meios para prevenir as crises. ${ }^{69}$

O trecho ilustra bem a imagem da burguesia criada por Marx (e intensamente recriada por cartunistas e chargistas desde o século XIX): homens poderosos que manipulam governos a seu bel-prazer para prevalecer seus interesses de classe. As frases grifadas na citação demonstram a utilização de interrogações que modalizam a interação com o leitor pois criam a sensação de construir juntos uma ideia, um compartilhamento de raciocínios, que reduz drasticamente a distância entre orador e auditório.

Uma vez identificado o "inimigo", o discurso transfere o protagonismo da burguesia para o proletariado. Com isso, inicia um processo que alimenta sensações de esperança ou confiança no auditório, como vemos em: "As armas que a burguesia utilizou para derrubar o feudalismo viraram-se agora contra ela própria. Mas a burguesia não forjou apenas as armas que lhe trazem a morte; também gerou os homens que vão manejar essas armas - a moderna classe trabalhadora - os proletários. ${ }^{70}$ É óbvio que deve haver um grande esforço interpretativo, suscetibilidade, identificação, disponibilidade do auditório para aderir ao discurso político proferido no Manifesto. $\mathrm{O}$ que vimos tentando de-

69 Ibid., p. 70, grifos nossos

70 Ibid., p. 70, grifo do autor 
monstrar é que o despertar das paixões caminha junto aos recursos linguísticos de que o orador dispõe, até porque é impossível separar os elementos fundantes da Retórica: o ethos, o pathos e o logos. Assim, temos o poder da palavra que cria efeitos patêmicos por meio do plano textual e discursivo.

A essa altura, chegamos ao que Figueiredo (2019) classifica como " $\mathrm{Mu}$ dança de julgamento", em sua Trajetória das paixões, em que o auditório sofre alterações em seus estados ou processos cognitivos relativamente a crenças ou julgamentos. Isso acontece, segundo a pesquisadora, por conta da "mudança ocorrida no espírito em função da experiência da dor e/ou prazer"71 e o que se espera em seguida é a ação do auditório que se esforçará para alterar a paisagem que se lhe apresenta. A relação sempre assimétrica da indignação, a considerar a hierarquia das paixões oferecidas por Figueiredo e Santos Júnior (2020), ${ }^{72}$ permite verificar a passagem da condição de inferioridade inicial para a condição de superioridade de quem se sente indignado. $\mathrm{O}$ alvo da indignação está nas cordas e pode ser nocauteado. É hora da ação.

Assim, em um tom que parte de constatações históricas e exemplos concretos das relações entre trabalho e capital, Marx vai assumindo um tom profético que se vale da inevitabilidade das ações futuras. Afirma ele:

Por fim, quando a luta de classes se aproxima da hora decisiva, o processo de dissolução no seio da classe dominante, no seio de toda a velha sociedade, assume um caráter tão agudo, tão violento, que uma pequena parte da classe dominante se desliga desta e se junta à classe revolucionária, à classe que traz nas mãos o futuro. Assim, tal como anteriormente uma parte da nobreza passou para a burguesia, também agora uma parte da burguesia se passa para o proletariado, e em particular uma parte dos ideólogos burgueses que conseguiram-se elevar-se ao nível de compreensão teórica do movimento histórico como um todo. ${ }^{73}$

Na segunda parte, Proletário e comunistas, o documento exalta as características dos comunistas e constrói um curioso diálogo destes com a burguesia. Cria, dessa forma, um interlocutor que questiona o discurso do Manifesto e que é refutado em seguida. Entre tantas passagens, destacamos a que segue:

\footnotetext{
$71 \quad$ Figueiredo, 2019, p. 15

72 Extraído da palestra da Dra. Maria Flávia Figueiredo: “Ampliação e aplicabilidade analítica da Trajetória das Paixões", ministrada na abertura do Ciclo de Palestras do Grupo PARE, em 25 set. 2020. Disponível em: https://www.youtube.com/watch?v=22Idmt4qhK4\&t=37s

73 Marx; Engels, 2015, p. 74-75
} 
Propriedade arduamente conquistada, fruto do trabalho, merecida a partir do próprio esforço! Refere-se à propriedade do pequeno artesão, do pequeno camponês, uma forma de propriedade que precedeu a forma burguesa? Não precisamos revogá-la, o desenvolvimento da indústria já a destruiu em grande parte e continua diariamente a destruí-la. Ou falais da moderna propriedade privada burguesa? ${ }^{74}$

(...) Horrorizai-vos por queremos suprimir a propriedade privada. Mas na sociedade existente, a vossa, a propriedade privada já está suprimida para nove décimos da população. ${ }^{75}$

O restante do discurso político do Manifesto apresenta os objetivos dos comunistas de forma programática, classifica as diferentes espécies de socialistas e comunistas e, na peroração, dispara o célebre enunciado: "Que as classes dominantes tremam ante uma revolução comunista! Nela os proletários nada têm a perder, a não ser os seus grilhões. Têm um mundo a ganhar. Proletários de todos os países, uni-vos!"76 É nítida a gradação de intensidade discursiva que culmina com a conclamação ao auditório, que é levado a uma adesão não apenas intelectual, como opera em partes o fazer-crer da disponibilidade e da identificação, mas também chegando a "adesões comportamentais", como o fazer-fazer da ação, e "emotivas", como o fazer-sentir do despertar das paixões e mudança de julgamento, conforme contribuições de Galinari (2014) e Figueiredo (2019).

Uma última consideração acerca de como o auditório pode ser afetado pelo ato retórico e o poder retórico do discurso de Marx pode ser constatado pelo discurso de seu colaborador e companheiro de estudos, em um discurso de elogio fúnebre, proferido diante do túmulo do amigo, no cemitério Highgate, em Londres, em 17 de março de 1883, do qual destacamos o trecho:

Marx era, antes do mais, revolucionário. Cooperar, desta ou daquela maneira, no derrubamento da sociedade capitalista e das instituições de Estado por ela criadas, cooperar na libertação do proletariado moderno, a quem ele, pela primeira vez, tinha dado a consciência da sua própria situação e das suas necessidades, a consciência das condições da sua eman- 
cipação - esta era a sua real vocação de vida. A luta era o seu elemento. E lutou com uma paixão, uma tenacidade, um êxito, como poucos. ${ }^{77}$

\section{Considerações finais}

O poder da Retórica está, obviamente, presente nos discursos políticos. $\mathrm{O}$ que varia de texto para texto, no entanto, é a qualidade imprimida pelo autor. Marx não foi apenas um filósofo engajado em uma luta política e ideológica. Ele produziu um conhecimento autêntico, fruto de décadas de leitura, pesquisa e reflexão. Em todo seu materialismo dialético, profetizou um mundo idealizado, sem classes, sem desigualdade, sem injustiças. Fez tudo isso valendo-se de um discurso repleto de imagens e lugares retóricos, a fim de despertar a indignação, a única das paixões aristotélicas que pode contribuir para a deflagração de transformações radicais. A tomada de consciência em um contexto retórico em que a paisagem é imperfeita e desfavorável a um segmento social.

No Manifesto do Partido Comunista, há não só a estrutura de um tratado político-partidário em que percebemos claramente o sistema retórico descrito por Aristóteles, mas também há uma comunhão de ideias supostamente compartilhadas pelo auditório universal. Em nossa análise, não coube discriminar se o discurso é constituído de enunciados com dicotomias valorativas como "falaciosos" ou "não falaciosos", "lógicos" ou "não lógicos", e "argumentativos" ou "retóricos". Buscamos identificar, conforme Galinari (2014), de forma pragmática, aquilo que é "eficiente para se produzir a adesão" ${ }^{78}$ Ora, se o discurso presente no Manifesto não fosse eficiente, não teria sobrevivido a 172 anos de acirramento entre segmentos sociais, de globalização do capital, de desenvolvimento tecnológico e de modos de produção, de reorganização geopolítica.

Mesmo que bem ou mal interpretado, o Manifesto (e os conceitos nele constantes) tem sido reformado ou distorcido, analisado ou criticado, respeitado ou desprezado. E, do ponto de vista dos estudos da linguagem e do discurso, seu autor é irrefutavelmente um "instaurador de discursos", que expressa uma subjetividade revelada por Chagas (2013) e um pensamento e linguagem modernos, observados por Berman (1986). Dessa forma, o discurso de Marx possui as condições necessárias para entrar no imaginário do leitor, criar suscetibilidades a partir das experiências emotivas compartilhadas com o auditório e conduzir à 
A paixão da indignação no discurso

político de Karl Marx

ação, que é o efeito esperado de qualquer discurso persuasivo, principalmente de cunho político.

Consideramos que a Trajetória das paixões, proposta por Figueiredo (2019), embasadas na análise de Meyer (2000) e nos estudos de Trueba Atienza (2009), e as dimensões discursivas das provas retóricas em equivalência não dicotomizadas, apresentadas por Galinari (2014), como instrumentos de análise para detectar o movimento suscitado no pathos contribuíram enormemente para nosso olhar sobre o Manifesto, como fruto de um ato retórico, e para verificação de como a combinação de palavras e sentimentos, percepções e impressões racionais existentes no auditório colaboram para a adesão a um discurso em contextos distanciados no espaço e no tempo. Enfim, a capacidade de se indignar, assim como as demais paixões aristotélicas, é o que nos faz humanos, é o predicado que traduz nossa essência de seres retóricos.

\section{Referências}

ARISTÓTELES. Retórica. São Paulo: Folha de S.Paulo, 2015. (Coleção Grandes nomes do pensamento. V. 1)

ARISTÓTELES. A retórica das paixões. São Paulo: Martins Fontes, 2000. Trad. grego: Isis Borges B. da Fonseca (Clássicos).

ARISTÓTELES. Ética a Nicômaco. Tradução e notas de Luciano Ferreira de Souza. São Paulo: Martin Claret, 2015b. (Coleção a obra-prima de cada autor; 53)

BAKHTIN, M. A estética da criação verbal. Introd. e trad. do russo: Paulo Bezerra. ed. 6. São Paulo: WMF Martins Fontes, 2011.

BAZERMAN, C. Retórica da ação letrada. Trad. Adail Sobral, Angela Paiva Dionísio, Judith Hoffnagel, Peitra Acunha. ed. 1. São Paulo: Parábola Editorial, 2015.

BERMAN, M. Tudo que é sólido desmancha no ar: a aventura da modernidade. Trad. Carlos Felipe Moisés, Ana Maria L. Ioriatti. São Paulo: Companhia das Letras, 1986.

CHAGAS, E. F. O pensamento de Marx sobre a subjetividade. Trans/Form/Ação, v.36, n.2, p. 63-84, mai./ago., 2013.

ENGELS, F. Discurso de Engels no túmulo de Marx. Germinal: Marxismo e Educação em Debate, Salvador, v. 10, n. 367-368, mai. 2018. Disponível em https://portalseer. ufba.br/index.php/revistagerminal/article/view/26655. Acessado em 15ago2020.

FERREIRA, L. A. Leitura e persuasão: princípios de análise retórica. São Paulo: Contexto, 2010. (Coleção Linguagem \& Ensino)

FIGUEIREDO, M. F.; VIDAL, G. R.; FERREIRA, L. A. (org.). Paixões aristotélicas. Franca, SP: Unifran, 2017. (Foco: linguística do texto e do discurso, 2)

FIGUEIREDO, M. F. A trajetória das paixões: Aristóteles, a Retórica das Paixões e suas implicações no contexto discursivo/argumentativo. Comunicação Científica, Cognição 
e Persuasão, v. 20, Edição Especial, 09set2019. Disponível em https://ojs.ifsp.edu.br/ index.php/sinergia/article/view/1101. Acessado em 15set2020.

FIGUEIREDO, M. F; SANTOS JUNIOR, V. F. Uma incursão ao pathos: o método aristotélico de descrição das paixões e a relação hierárquica delas emanada. In: FERREIRA, L. A. (Org.). Inteligência retórica: o pathos. São Paulo: Blucher, 2020. (no prelo) FIGUEIREDO, M. F. Ampliação e aplicabilidade analítica da "trajetória das paixões". In: FIGUEIREDO, M. F.; GOMES, A. M.; FERRAZ, L. (Orgs.). Trajetória das paixões: uma retórica da alma. Franca: Unifran, 2020. (no prelo)

FOUCAULT, M. O que é um autor? França: Bulletin de la Societé Française de Philosophic, 63. ano, n. 3, julho-setembro de 1969, p 73-104. (Societé Française de Philosophie, 22 de fevereiro de 1969; debate com M. de Gandillac, L. Goldmann, J. Lacan, J. d'Ormesson, J. Ullmo, J. Wahl).

GALINARI, M. M. Logos, ethos e pathos: "três lados" da mesma moeda. Alfa, São Paulo, 58 (2): 257-285, 2014. Disponível em http://dx.doi.org/10.1590/1981-57941405-1. Acessado em 21dez2019.

MARX, K. Diferença entre as filosofias da natureza em Demócrito e Epicuro. Trad. Conceição Jardim e Eduardo Lucio Nogueira. Tese de Doutoramento, Universidade de Iena. Santos (SP): Editorial Presença/Martins Fontes, 1972. (Coleção Clássicos).

MARX, K. O 18 Brumário de Luís Bonaparte. Trad. e notas: Nélio Schneider; prólogo Herbert Marcuse. São Paulo: Boitempo, 2011. (Coleção Marx-Engels).

MARX, K; ENGELS, F. O Manifesto do Partido Comunista. Trad. prefácio e notas: Edmilson Costa. ed.3. São Paulo: Edipro, 2015.

MARX, K; ENEGELS, F. Manifest der Kommunistischen Partei. Amsterdã, Lausanne, Melbourne, Milan, New York, São Paulo: Metal Libri, 2008. Disponível em <https:// www.ibiblio.org/ml/libri/e/EngelsFMarxKH_ManifestKommunistischen_s.pdf >. Acessado em 20mar2020.

MARX, K. Theorien über den Mehrwert. In: MARX, K.; ENGELS, F. Werke (MEGA). Berlin: Dietz, 1965, v. 26.

MARX, K. Prefácio. Para a crítica da Economia Política. Trad. José Barata-Moura. Lisboa/Moscovo: Avante, 1859. Disponível em: https://www.marxists.org/portugues/ marx/1859/01/prefacio.htm. Acessado em 20jul2020.

MEYER, M. Aristóteles ou a retórica das paixões. In: ARISTÓTELES. A retórica das paixões. Trad. grego: Isis Borges B. da Fonseca. São Paulo: Martins Fontes, 2000, p. XVII-LI. (Clássicos).

MOSCA, L. S. Paixões, emoções e afetividade na trilha do tempo: lugar no discurso. In: FIGUEIREDO, M. F.; VIDAL, G. R.; FERREIRA, L. A. (org.). Paixões aristotélicas. Franca, SP: Unifran, 2017, p. 15-29. (Foco: linguística do texto e do discurso, 2)

O JOVEM Karl Marx. Direção de Raoul Peck. França-Alemanha-Bélgica: California Filmes, 2016. 1 DVD (118 min.).

TRUEBA ATIENZA, C. La teoría aristotélica de las emociones. Signos filosóficos, México, v. 11, n. 22, jul./dic. 2009. 